\title{
The collet-sicard syndrome and dentistry: case report
}

\author{
Sindrome de collet-sicard e odontologia: relato de caso
}

Felipe BRAVO'

(iD) ORCID iD 0000-0002-5404-5904

Sérgio Bartolomeu de Farias MARTORELLI ${ }^{1}$

(D) ORCID iD 0000-0002-0251-1475

Fernando de Oliveira MARTORELLI

(iD) ORCID iD 0000-0001-7985-4639

Felipe Leonardo de Melo Almeida FONSECA ${ }^{1}$

(i) ORCID iD 0000-0001-7967-0215

\begin{abstract}
The Vernet, Collet-Sicard and Villaret Syndromes are uncommon; they affect the spaces through which some of the cranial nerves pass and can lead to the impairment of motor functions of the tongue. The etiology is variable, including benign or malignant tumors, metastasis, infections, or Idiopathic causes. Patients with the disease may report changes in the mobility and function of the tongue, dysphonia, dysarthria and dysphagia. The purpose of this article was present a case report of Collet-Sicard syndrome, and to highlight the importance of proper diagnosis by dentists. Appropriate treatment must be instituted as soon as possible and the patient should be treated by a multidisciplinary team until the complete remission of symptoms.
\end{abstract}

Indexing terms: Neoplasms. Syndrome. Tongue.

\section{RESUMO}

As síndromes de Vernet, Collet-Sicard e Villaret são pouco frequentes que acometem os espaços por onde passam alguns dos pares de nervos cranianos que podem ocasionar o comprometimento das funções motoras da língua. A etiologia dessas patologias podem ser oriundas de tumores benignos ou malignos, metástases, infecções, ou serem consideradas

Idiopáticas. Pacientes que apresentam a doença, podem relatar alterações de mobilidade e função da língua, disfonia, disfagia e disartria. O objetivo deste artigo é relatar um caso sobre a síndrome de Collet-Şicard, ratificando a importância do cirurgião-dentista no diagnóstico de doenças que se manifestam na cavidade oral. O tratamento adequado deve ser instituído o mais rápido possível e o paciente deve ser acompanhado por uma equipe multiprofissional para possibilitar a remissão completa dos sintomas.

Termos de indexação: Neoplasias. Síndrome. Língua.

\section{INTRODUCTION}

The Vernet, Collet-Sicard and Villaret syndromes are uncommon entities that affect the spaces through which some of the pairs of cranial nerves pass, and may compromise the motor functions of the tongue. Some lesions may occur in the brainstem, subarachnoid space, and base of the skull; that is, along the trajectory of the nerves. Paralysis of the pairs of cranial nerves may be single or multiple; begin in one cranial pair and later concomitantly affect other nerves [1].

The space through which the carotid artery and internal jugular vein, glossopharyngeal (IX), vagus $(X)$, accessory (XI) and hypoglossal nerves (XII) pass is the parapharyngeal space, defined as virtual space that separates the deep lobe of the parotid gland and the soft parts of the nasopharynx $[2,3]$.

Compromise of this space originates neurological syndromes that express signs of unilateral extracranial suffering of the bulbar cranial nerves, and these have become known by both the names of the authors who described them and by the anatomical region affected [4].

The Vernet [5] syndrome, or jugular foramen syndrome compromises the cranial nerves IX, X and XI. Whereas, in the Collet-Sicard syndrome or the posterior lacerocondylar space syndrome, paralysis of half of the tongue additionally occurs, because the cranial nerve XII

\footnotetext{
${ }^{1}$ Faculdade de Odontologia do Recife. Rua Artur Coutinho, 143, Santo Amaro, 50100-280, Recife, PE, Brasil. Correspondência para / Correspondence to: F BRAVO. E-mail: <felipebravomachado@gmail.com>.

${ }^{2}$ Força Aérea Brasileira, Odontoclínica de Aeronáutica de Recife. Recife, PE, Brasil.

$\boldsymbol{\nabla} \boldsymbol{\nabla} \boldsymbol{v}$

Como citar este artigo / How to cite this article

Bravo F, Martorelli SBF, Martorelli FO, Fonseca FLMA. The Collet-Sicard syndrome and Dentistry: case report. RGO, Rev Gaúch Odontol. 2018;66(2):0000. http://dx.doi.org/10.1590/1981-8637201800020000123237
} 
is affected, due to compromise of cranial nerves IX, X and $\mathrm{XI}$, verified through the Vernet syndrome [6]. The Villaret syndrome is a rare pathology that promotes selective and homolateral compromise of the four last bulbar cranial nerves and the cervical sympathetic pathway [7]. Patients with these pathologies present dysphonia, dysphagia and dysarthria, paralysis, paresthesia [1], according to the compromise demonstrated in Figure 1.

\section{Pares de Nervos:}

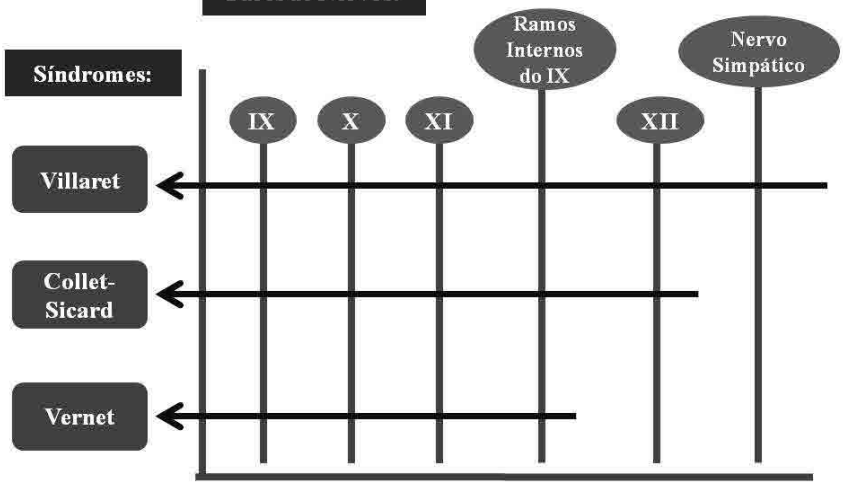

Figure 1. Description of the search strategy and where to find the publications in each step.

The etiology of these pathologies may arise from benign or malignant tumors [7,8] metastases [9], and infections [10], or be considered idiopathic [11].

The aim of this article was to highlight the importance of dentists' knowledge about adequate diagnosis of the syndromes presented.

\section{CASE REPORT}

The patient C.K.A, 46 years of age, melanoderma, presented to the private dental office for evaluation of a "disease in the tongue". In the anamnesis, he reported being a smoker for the last 20 years (20 cigarettes per day), however, he presented no health problem. He did not use any medications and reported no allergies.

The patient informed that he perceived an increase in the volume of the tongue 6 months previously, associated with loss of sensitivity and difficulty with movement. He reported dysphagia, hoarseness and discomfort in the trapezius muscle, as well as earaches for some time. He affirmed that he had visited specialists in the area, but that no diagnosis had been defined.

On extraoral physical exam, no significant changes were diagnosed in the face, submandibular, submental, and cervical regions. On intraoral exam, an increase in the volume of the tongue on the left side was perceived. This had a soft consistency, associated with a depapillated area, with diminished tactile sensitivity throughout the region of the right half of the tongue. There was no change in color. The change in the contour of the tone was related to hypomobility perceived by the patient, giving the impression that when in the position of rest, the increase in volume was much larger than the volume effectively verified. The patient had precarious oral hygiene, with biofilm accumulation on the surface of the teeth and tongue. The possibility of fungal colonization associated with the dorsum of the tongue was not overlooked. The patient presented difficulty with moving the tongue and making movements of lifting it and swallowing. There was no area of ulceration and the affected region was traumafree. The initial aspect is shown in Figures 2 and 3.

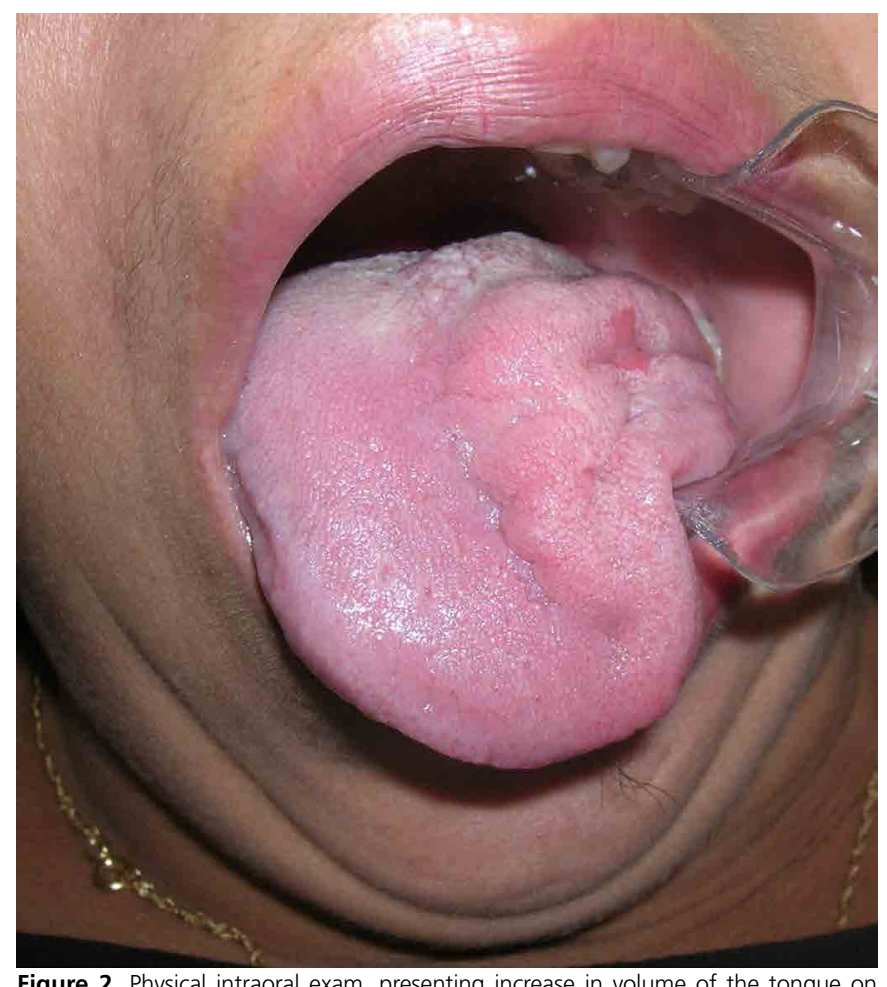

Figure 2. Physical intraoral exam, presenting increase in volume of the tongue on the left side.

As a complementary exam, magnetic resonance with contrast was requested, considering that one of the diagnostic hypotheses would be that the vagus, accessory and hypoglossal nerves were affected. The sections showed a well delimited lesion localized in the parapharyngeal space (Figures 4 and 5). The exam report made references to the Vernet, Collet-Sicard and Villaret syndromes, and that the definitive diagnosis must be made by means of the clinical correlations. 
Therefore, the patient was instructed and referred to the Neurologist to perform the required treatment. Surgery was performed, but the patient did not return for dental follow-up.

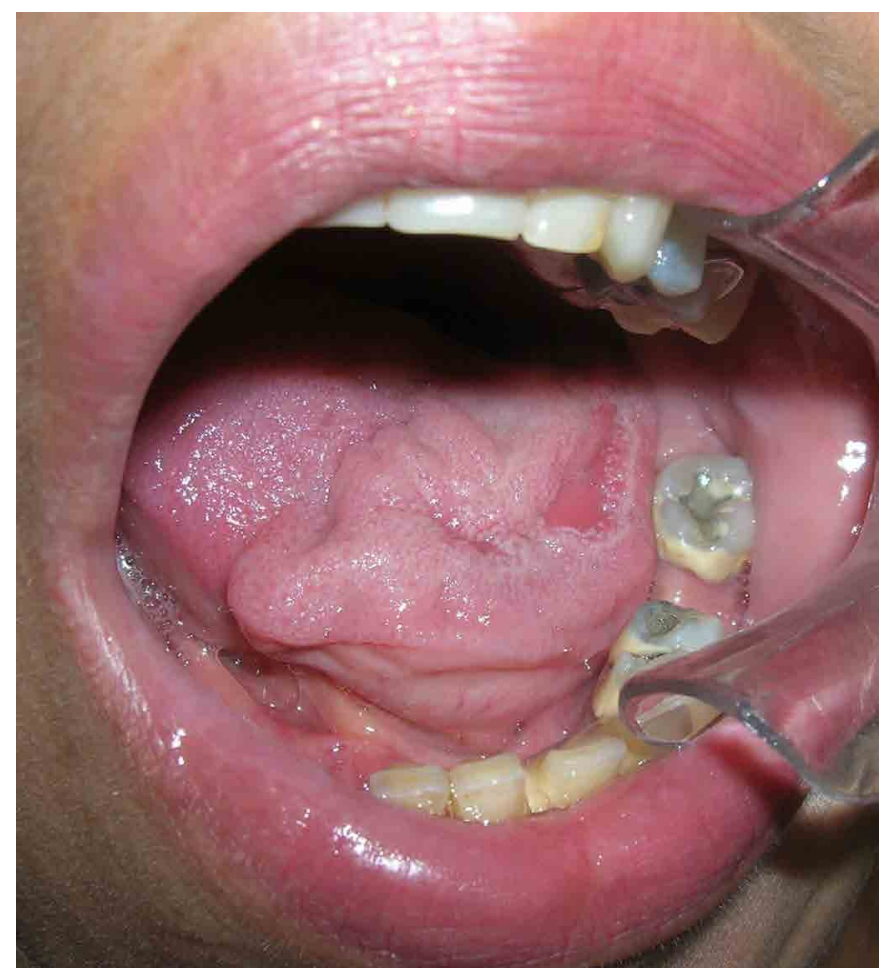

Figure 3. Physical intraoral exam, presenting association of the depapillated area, with diminished tactile sensitivity.

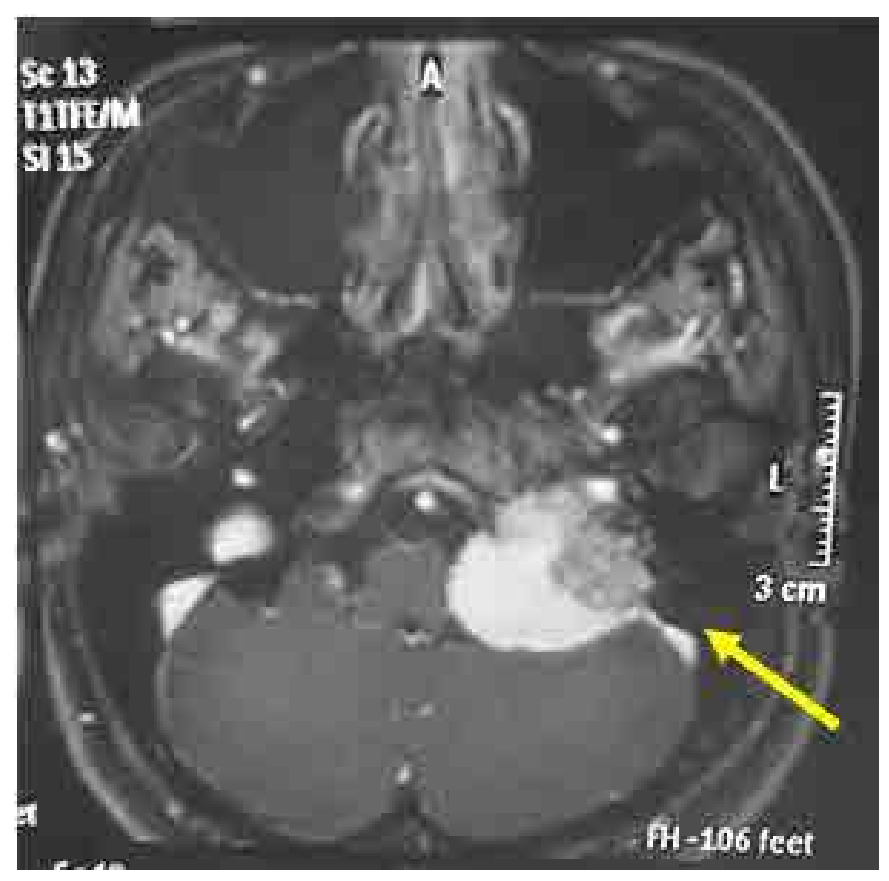

Figure 4. Transverse section of the magnetic resonance exam with contrast. A well circumscribed lesion was observed in the parapharyngeal region.

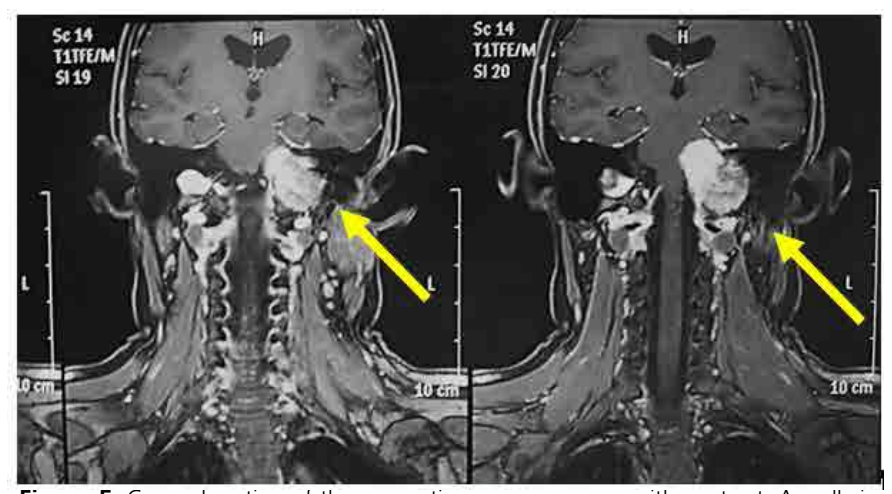

Figure 5. Coronal section of the magnetic resonance exam with contrast. A well circumscribed lesion was observed in the parapharyngeal region.

\section{DISCUSSION}

The parapharyngeal space may be affected by several pathologies (such as tumors), causing repercussion on the nerves that pass through the region. In the majority of cases, the clinical diagnosis determines the type of syndrome from specific signs, developed in the patient. Due to the little space existent at the base of the skull, and according to the proximity of the anatomic structures, frequently, one syndrome may evolve into another, as a result of compression of the nerves.

In the Vernet syndrome, compromise of the pairs of cranial nerves ( $(I X, X$ e $X I)$ on the same side are known to occur, leading to compressive lesions of the structures involved [4].

The Villaret syndrome is characterized by compromise of the pairs of nerves IX, X, XI and XII and the involvement of the cervical sympathetic pathway. This syndrome clinically presented by means of paresis or paralysis of the soft palate, pharynx and larynx, and may cause dysphonia; dysphagia; desensitization of the palate, and reduction or loss of the sense of taste in the posterior $1 / 3$ of the tongue. In addition, there may also be partial loss of the motor functions of the sterno-cleido-mastoid-occipital muscle and part of the trapezius with inability to move the shoulder and possible changes in the contour of the neck. Due to involvement of the cervical sympathetic ganglia or brainstem nuclei in some cases, a reduction is verified in the eyelid ptosis, myosis (pupillary constriction), enophthalmia (a sunken appearance of the eye) and anhydrosis (loss of sweating on one side of the face), characterizing the Horner syndrome [7].

Whereas, the Collet-Sicard is characterized by paralysis of half of the tongue ipsilateral to pair of cranial 
nerves XII associated with compromise of the pairs of cranial nerves $I X, X$ and $X \mid[6]$.

In the case reported, the patient presented not only the characteristics signs of compromised nerves IX, X and XI, but also paralysis of half of the tongue due to involvement of the glossopharynx (XII). These signs suggested the diagnosis of Collard-Sicard syndrome. Because he did not present any sign of Horner (reduction in eyelid drop, miosis, enophthalmia, and anhidrosis at the time of diagnosis, the Villaret syndrome was discarded.

It is worth emphasizing that in addition to tumors, metastases, infections, osteomyelitis, venous thrombosis, arterial dissection and fractures may be involved in the appearance of these syndromes. Some reports have been unable to identify a specific cause.

The treatment of first choice is surgery, but the way of approach depends on the localization and extension of the tumor. Treatment of the syndrome depends on the cause, but the stereotypical aspect and neurological condition must be promptly recognized because they point towards the specific anatomic localization.

Signs com compromised motricity and lingual anatomy must be carefully evaluated by the Dentist. The possibility of compromise of the sensitive and motor nerves that innervate the region must always be investigated by

\section{REFERENCES}

1. Carroll CG, Campbell WW. Multiple cranial neuropathies. Semin Neurol. 2009;29(1):53-65. doi: 10.1055/s-0028-1124023.

2. Monkhouse S. Cranial nerves functional anatomy. Cambridge: Cambridge University Press; 2006.

3. Nancy Lee, Colevas AD, Fu KK. Cancer of the nasopharynx. Head and Neck Tumors. Part 2 [cited 2017 Set 14]. Available from: <http:// health-7.com/Textbook\%20of\%20Radiation \%20 Oncology $/ 27 \% 20 \%$ E2 \% $80 \% 93 \% 20$ Cancer \% 20 of \% 20 the $\% 20$ Nasopharynx>.

4. Liu GT, Crenner CW, Logigian EL, Charness ME, Samuels MA. Midbrain syndromes of Benedikt, Claude, and Nothnagel: setting the record straight. Neurology. 1992 Sep;42(9):1820-2.

5. Lustig LR, Jackler RK. The variable relationship between the lower cranial nerves and jugular foramen tumors: implications for neural preservation. Am J Otol. 1996;17(4):658-668.

6. Gorlin R, Cohen M, Hennekan RCM. Syndromes of head and neck. 4th ed. New York: Oxford University Press; 2001. means of complementary exams (tomography, magnetic resonance imaging, rhinoscopy, laryngoscopy) when no local cause is identified in the intraoral evaluation. Precise diagnosis is frequently neglected, and the patient goes without precise diagnosis and ideal treatment for months or years.

\section{CONCLUSION}

The Dentist must be familiarized with the functional and anatomic changes in the tongue, and is the professional most indicated for identifying diseases that affect the glossopharyngeal, accessory and hypoglossal nerves. Precise diagnosis may be made by the Dental professional, so that adequate treatment is instituted as quickly as possible, particularly when the cause is a neoplasm and the patient must be followed-up by a multiprofessional team to ensure complete remission of the symptoms.

\section{Collaborators}

F BRAVO, SBF MARTORELLI, FO MARTORELLI and FLMA FONSECA participated in all stages of preparation of the article.

7. Schattner A, Mate A, Lahav G, Adi M. Dysphagia and dysphonia in a patient with cancer. Am J Med Sci. 2009;338(3):236-237.

8. Parvinderjit S. K, Gandotra P. Small Cell Bronchogenic Carcinoma Presenting as Collet-Siccard Syndrome. Indian J Otolaryngol Head Neck Surg. 2011;63(Suppl 1):29-32. doi: 10.1007/ s12070-011-0180-3

9. Agarwal A, Baisakhiya N, Kakani A, Bhake A, Nagrale M, Reddy S. Metastatic lung cancer presenting with jugular foramen syndrome in a case of von Recklinghausens disease. J Cancer Res Ther. 2010 Jul-Sep;6(3):391-3. doi: 10.4103/0973-1482.73344.

10. Kawabe K, Sekine T, Murata K, Sato R, Aoyagi J, Kawase Y, et al. A case of Vernet syndrome with varicella zoster virus infection. J Neurol Sci. 2008 Jul 15;270(1-2):209-10. doi: 10.1016/j. jns.2008.03.005.

11. Tanaka M, Zsaka K-I, Morimatsu M. Hira S. Jugular foramen syndrome. Neurology. 1983;32:119-120.

Received on: 19/5/2017 Final version resubmitted on: 14/11/2017 Approved on: 19/12/2017 